\title{
Phenology and Yield of Baby Corn (Zea mays var. rugosa) as Influenced by Thermal Regime
}

\author{
Sanjay Bairagi ${ }^{1^{*}}$, Abhijit Saha ${ }^{2}$,M. K. Pandit ${ }^{3}$ and Arindam Das ${ }^{4}$ \\ ${ }^{1}$ College of Agriculture, Extended Campus of BCKV, Bankura, West Bengal, India \\ ${ }^{2}$ Department of Agricultural Meteorology, BCKV, Nadia, West Bengal, India \\ ${ }^{3}$ Department of Vegetable Science, BCKV, Mohanpur, Nadia, West Bengal, India \\ ${ }^{4}$ Department of Vegetable \& Spice Crops, UVKV, Pundibari, Coochbihar, West Bengal, India \\ *Corresponding author
}

\begin{abstract}
A B S T R A C T
Baby corn is the ear and diversified product of maize plant harvested young, especially when the silks have either not emerged or just emerged, and no fertilization has taken place. Field experiments were conducted during October-March, 2012-13 and 2013-14to study the impacts of thermal regime on phenology and yield of baby corn. Thermal environment during reproductive phase of baby corn contributed more towards the yield formation process, as compared to that during vegetative phases. Among yield components, ear diameter showed consistently negative correlation with thermal environment whereas cob and fodder yield showed consistently positive correlation with the thermal environment. Among weather variables during vegetative stage, maximum temperature was found to be best indicator of cob yield. The difference in heat use efficiency (HUE) values among the dates of sowing was statistically significant. Baby corn sown at $15^{\text {th }}$ February recorded highest HUE vis-a-vis baby corn yield, which might be associated with the exposure of average maximum temperature beyond $35^{\circ} \mathrm{C}$ that favoured the crop yield level to its maximum. The growth and yield parameters of baby corn are clearly indicative that they are thermo- sensitive and the crop performs better at higher thermal regimes.
\end{abstract}

\section{Introduction}

Baby corn is the ear and diversified product of maize plant harvested young, especially when the silks have either not emerged or just emerged, and no fertilization has taken place. The dehusked young ears of baby corn are eaten as a vegetable. The important attributes relevant to baby corn are early maturity, prolificacy (ability to produce multiple ears), synchronized ear emergence and yellow kernels (Kumar and Kallo, 1998). Ear quality, not quantity is the primary criterion of baby corn and ears should be 2-4 inches long and $1 / 3-2 / 3$ inch in diameter at the base (Chutkaew and Paroda, 1994). Cultural requirement is same as that of maize but topping or detusseling is important to baby 
corn for its quality ears. If topping or detusseling is not done properly, fertilization will occur which reduce the quality of corn. Baby corn can be grown throughout the year but its growth and yield potential vary across the growing season. Thermal environment during reproductive phase of baby corn contributed more towards the yield formation process, as compared to that during vegetative phases. Among yield components, ear diameter showed consistently negative correlation with thermal environment whereas cob and fodder yield showed consistently positive correlation with the thermal environment. The total accumulated heat at maturity is called Summation Constant or Remainder Index, which may predict on a long term basis the probable maturity time of a crop (Shanmugavelu, 1989).

\section{Materials and Methods}

Field experiments were conducted at the $A B$ Block Seed Farm of Bidhan Chandra Krishi Viswavidyalaya, Kalyani, Nadia, West Bengal (Lat $22.99^{\circ} \mathrm{N}$, Long $88.43^{\circ} \mathrm{E}$ ) during October-March, 2012-13 and 2013-14. The present experiment was conducted with variety G-5414 in a split plot design with five levels of date of planting viz. 15th October (D1), 15th November (D2), 15th December (D3), 15th January (D4) and 15th February (D5),and three levels of plant population having three replications. Five levels of date of planting were allotted in the main plots and three levels of plant population were allotted randomly in the subplots. So, the treatment combinations are $5 \times 3$ i.e. 15 , replicated thrice. Therefore, the total number of plots was $5 \times 3 \times 3=45$. Each sub plot size was $3 \times 2.25 \mathrm{~m}$ $=6.75$ sq.m, accommodating 50, 75 and 150 plants per plot for 30,20 , and $10 \mathrm{~cm}$ plant to plant distance, respectively. Observations taken were plant height $(\mathrm{cm})$, days to $50 \%$ germination, days to $50 \%$ flowering, cobs /plant, ear length $(\mathrm{cm})$, ear diameter $(\mathrm{cm})$, ear weight (g), cob yield (quintal/ha) and fodder yield (quintal/ha). Date of occurrences of phenophases like, plant emergence, $50 \%$ flowering, emergence of cobs and harvesting were recorded. Accordingly, weather parameters and derivatives pertaining to plant emergence to $50 \%$ flowering $\left(\mathrm{P}_{1}\right), 50 \%$ flowering to emergence of cobs $\left(\mathrm{P}_{2}\right)$, emergence of cobs to harvesting $\left(\mathrm{P}_{3}\right)$, plant emergence to cob emergence $\left(\mathrm{P}_{4}\right), 50 \%$ flowering to harvesting $\left(\mathrm{P}_{5}\right)$ and plant emergence to harvesting $\left(\mathrm{P}_{6}\right)$ were also studied. Weather related parameters like, Growing Degree Day (GDD), calculated with a base temperature $\left(\mathrm{T}_{\mathrm{b}}\right)$ of $6.6^{\circ} \mathrm{C}$ (Borowiecki, 1992), Heat Use Efficiency (HUE), Day Temperature(DT), Night Temperature(NT), Accumulated Diurnal Variation of Temperature (AcDVT) pertaining to those phenological stages were also estimated to study the development and productivity of the crop. Parameters were measured using following relations.

\begin{tabular}{ccl}
\hline Parameter & Relationship & \multicolumn{1}{c}{ Reference } \\
\hline $\begin{array}{c}\text { GDD } \\
\left({ }^{\circ} \mathrm{C}-\text { days }\right)\end{array}$ & $\mathrm{GDD}=\sum_{\mathrm{i}=1}^{\mathrm{n}} \frac{|\mathrm{Tmax}+\mathrm{Tmin}|}{2}-\mathrm{Tb}$ & - \\
$\mathrm{HUE}$ & Yield & - \\
$\left(\mathrm{Kg} / \mathrm{Ha} /{ }^{\circ} \mathrm{C}\right.$ & $(\mathrm{Kg} / \mathrm{Ha}) / \mathrm{GDD}$ & \\
$\mathrm{DT}\left({ }^{\circ} \mathrm{C}\right)$ & $\mathrm{TMax}-0.4$ & Venkatraman \\
& $(\mathrm{TMax}-\mathrm{TMin})$ & and \\
& & Krishnan, \\
& & 1992 \\
$\mathrm{NT}\left({ }^{\circ} \mathrm{C}\right)$ & $\mathrm{TMin}+0.4$ & Venkatraman \\
& $(\mathrm{TMax}-\mathrm{TMin})$ & and \\
& & Krishnan, \\
& & 1992 \\
AcDVT & $\sum(\mathrm{DT}-\mathrm{NT})$ & - \\
\hline
\end{tabular}

The soil was sandy loam in texture with $\mathrm{pH}$ about 6-6.5. The crop was fertilized @ $100 \mathrm{~kg}$ $\mathrm{N}, 60 \mathrm{~kg} \mathrm{P}_{2} \mathrm{O}_{5}$ and $60 \mathrm{~kg} \mathrm{~K}_{2} \mathrm{O}$ per hectare. FYM was applied @ 20 t/ha before four weeks of sowing. Young cobs were harvested 2-3 days after silking or 60-65 days after plant emergence and the harvesting was done by hand picking. 


\section{Results and Discussion}

In order to find out the degree of association between various weather parameters pertaining to phenophases of Baby corn and yield and yield components of this crop, correlation coefficients were estimated and presented in Table-1. Data revealed that phenophasic weather parameters had a statistically significant degree of association with ear diameter, cob yield and fodder yield. However, other yield components like ear length, No. of cobs/plant and cob weight had no such significant relationship. It was noted that thermal environment during reproductive phase of baby corn contributed more towards the yield formation process, as compared to that during vegetative phases.

Among these three crop parameters, ear diameter showed consistently negative correlation with thermal environment whereas cob and fodder yield showed consistently positive correlation with the thermal environment. This might be due to the fact that cobs took longer days to mature when they were sown during early to mid winter $\left(D_{1}, D_{2}, D_{3}\right)$ whereas cobs took lesser number of days to mature when they were sown during late winter to early summer $\left(D_{4}, D_{5}\right)$. During latter dates of sowing, cobs matured early mostly due to higher ambient temperature regime which favoured the cob yield and at the same time good quality cobs. Vanaja et al., (2017), reported the same as higher temperature significantly lowered the time to $50 \%$ flowering and total crop duration in maize. However, during earlier dates of sowing cobs took longer time to develop as the ambient temperature was low and this favoured the crop in attaining higher cob diameter (poor quality cobs) despite lower yield at harvest. Since baby corn with small girth or diameter has more market value compare to those with large diameter, sowing of crop during late winter and early summer is preferred over early plantings.
Among the weather parameters, maximum temperature for all phenophase combinations showed consistently significant correlation with cob yield at harvest. However, other parameters pertaining to the vegetative stage of crop did not show any significant correlation with cob yield at harvest indicating thereby that the maximum temperature during vegetative phase is best indicator of cob yield. Among the weather variables, GDD and AcDVT showed poorer correlation with cob yield as compared to others. AcDVT, among the weather parameters, particularly during cob development stage showed strong negative correlation with cob yield at harvest, implying that shorter the difference between day-time and night-time thermal regime, greater will be the prospect of cob yield at harvest. El Shaer et al., (1991) also reported that summer season sowings (i.e. with smaller diurnal variation of temperature) reduced the time for seedling emergence, the period to silking and physiological maturity. Growing Degree Days (GDD) required for emergence and physiological maturity were 80 and $1952{ }^{\circ} \mathrm{C}$ days, respectively. Delaying sowing by 9 weeks reduced GDD by up to $200{ }^{\circ} \mathrm{C}$-days. The degree of association between weather variables at various phenophases with fodder yield of baby corn showed similar trend as recorded in case of cob yield but the magnitude of correlation for most of the weather variables were little higher than those with cob yield.

In order to study the consistencies of various weather parameters pertaining to different phenophase of baby corn, coefficients of variabilities of these weather parameters were estimated across date of sowing and presented in Table-2. Study of these tables showed that $\mathrm{CV} \%$ of most of the weather parameters were lowest during $\mathrm{P}_{1}$ stage indicating the fact that sowing to $50 \%$ flowering stage of Baby corn received increasingly stable weather condition 
as compare to other phenophases when the sowing operation was stretched from October to February. In contrast, the highest coefficients of variabilities of most of the weather parameters were recorded at $\mathrm{P}_{2}$ phenophase, which indicated that $50 \%$ flowering to cob emergence stage of baby corn were exposed to maximum variability of weather parameters due to shift to dates of sowing from October to February. These variabilities of weather parameters at different phenophases were reflected in the variabilities of yield components of yield at harvest.

Variabilities of the duration of different phenophase across the dates of sowing were summarized and presented in Table-3. The mean duration of emergence to $50 \%$ flowering $\left(\mathrm{P}_{1}\right), 50 \%$ flowering to emergence of cobs $\left(\mathrm{P}_{2}\right)$ and emergence of cobs to harvest $\left(\mathrm{P}_{3}\right)$ were 59.3, 5.2 and 12.2 days, respectively.

Among the phenophases, the highest duration of $\mathrm{P}_{1}$ stage (63.5 days) was associated with $\mathrm{D}_{3}$, whereas the maximum duration of $\mathrm{P}_{2}(6.5$ days) and $\mathrm{P}_{3}$ (14.5 days) stages were associated with $D_{1}$ date of sowing. When the entire crop growth stage was considered $\left(\mathrm{P}_{6}\right)$, the maximum duration of 82 days was associated with $\mathrm{D}_{2}$ date of sowing. Studying the corresponding weather parameters pertaining to the different phenophase vis avis dates of sowing, it was revealed that the duration of phenophases were mostly associated with Tmax and AcDVT.

Lowest average temperature of $25^{\circ} \mathrm{C}$ and highest AcDVT of $227.4^{\circ} \mathrm{cd}$ was associated with the highest crop duration of 82 days, when the crop was sown during November $\left(D_{2}\right)$. Duration of Baby corn growth stages, were thus, directly proportional to AcDVT and inversely proportional to average Tmax. Detailed studies from correlation coefficients across all weather parameters and phenophase combinations, weather variables pertaining to a particular phenophase showing maximum degree of association with cob yield were identified and their impacts on cob yield were presented in more detail manner in Fig-1. Data revealed that all the weather variables corresponding to entire reproductive stage, except AcDVT, contributed substantially towards cob yield and more than 90\% variability of cob yield could be attributed to each of these weather variables. Since variables showed a strong positive correlation with the cob yield within the range of values of atmospheric variables experienced during the period of experimentation, no optimum values of this weather parameter were identified. Always, the highest values of this parameter were associated with highest cob yield. Only one weather variable i.e., AcDVT during the emergence to harvest $\left(\mathrm{P}_{3}\right)$ showed a strong negative relationship with cob yield at harvest.

The relationship indicates comparatively higher difference of day and night temperature that prevails during winter period is not conducive for higher cob yield. This phenomena also corroborated by Hemalatha et al., (2013), where they revealed that higher accumulation of heat units increased yield in maize, while lower accumulation of heat units resulted low yield. On the contrary, comparatively lower difference between day and night temperatures as prevailed during summer contributed positively towards cob yield at harvest. Accumulated diurnal variation of temperature during $\mathrm{P}_{3}$ phenophase could explain $60 \%$ variability of cob yield at harvest. This relationship can well be utilized for estimating cob yield from weather information.

Heat use efficiencies as estimated from dividing cob yield with accumulated GDD values were presented in Table-4. 
Table.1 Correlation coefficient between phenophasic weather parameters and yield component and yield of baby corn

\begin{tabular}{|c|c|c|c|c|c|c|c|}
\hline & \multicolumn{7}{|c|}{ No. of Cobs/Plant } \\
\hline & Tmax & Tmin & Tavg & GDD & ADT & ANT & AcDVT \\
\hline $\mathbf{P}_{1}$ & -0.28 & -0.05 & -0.18 & -0.34 & -0.18 & -0.12 & -0.31 \\
\hline $\mathbf{P}_{2}$ & -0.43 & -0.36 & -0.4 & -0.40 & -0.35 & -0.35 & 0.15 \\
\hline $\mathbf{P}_{3}$ & -0.19 & -0.21 & -0.20 & -0.08 & -0.20 & -0.20 & 0.30 \\
\hline $\mathbf{P}_{4}$ & -0.40 & -0.28 & -0.35 & -0.36 & -0.31 & -0.30 & -0.33 \\
\hline $\mathbf{P}_{5}$ & -0.32 & -0.29 & -0.30 & -0.19 & -0.29 & -0.29 & 0.29 \\
\hline \multirow[t]{3}{*}{$\mathbf{P}_{6}$} & -0.33 & -0.27 & -0.30 & -0.34 & -0.28 & -0.27 & -0.17 \\
\hline & \multicolumn{7}{|c|}{ Ear Length (cm) } \\
\hline & Tmax & Tmin & Tavg & GDD & ADT & ANT & AcDVT \\
\hline $\mathbf{P}_{1}$ & -0.40 & -0.27 & -0.33 & -0.403 & -0.32 & -0.30 & -0.029 \\
\hline $\mathbf{P}_{2}$ & -0.40 & -0.42 & -0.41 & -0.30 & -0.40 & -0.42 & 0.40 \\
\hline $\mathbf{P}_{3}$ & -0.21 & -0.31 & -0.27 & -0.17 & -0.25 & -0.28 & 0.51 \\
\hline $\mathbf{P}_{4}$ & -0.42 & -0.41 & -0.42 & -0.406 & 0.40 & -0.40 & 0.04 \\
\hline $\mathbf{P}_{5}$ & -0.32 & -0.38 & -0.34 & -0.22 & -0.33 & -0.35 & 0.51 \\
\hline \multirow[t]{3}{*}{$\mathbf{P}_{6}$} & -0.37 & -0.39 & -0.37 & -0.40 & -0.37 & -0.38 & 0.25 \\
\hline & \multicolumn{7}{|c|}{ Ear diameter(cm) } \\
\hline & Tmax & Tmin & Tavg & GDD & ADT & ANT & AcDVT \\
\hline $\mathbf{P}_{1}$ & -0.40 & -0.13 & -0.28 & -0.19 & -0.27 & -0.21 & -0.23 \\
\hline $\mathbf{P}_{2}$ & $-0.81 *$ & $-0.74 *$ & $-0.74 *$ & -0.403 & $-0.73 *$ & $-0.75^{*}$ & 0.60 \\
\hline $\mathbf{P}_{3}$ & $-0.79 *$ & $-0.82 *$ & $-0.80 *$ & $-0.75^{*}$ & $-0.80 *$ & $-0.81 *$ & $0.87 *$ \\
\hline $\mathbf{P}_{4}$ & $-0.64 *$ & -0.60 & -0.62 & $-0.21 *$ & -0.61 & -0.60 & -0.11 \\
\hline $\mathbf{P}_{5}$ & $-0.77 *$ & $-0.80 *$ & $-0.80 *$ & $-0.72 *$ & $-0.79 *$ & $-0.80 *$ & $0.89 *$ \\
\hline \multirow[t]{3}{*}{$\mathbf{P}_{6}$} & $-0.73^{*}$ & -0.72 & $-0.73 *$ & -0.37 & $-0.72 *$ & $-0.72 *$ & 0.21 \\
\hline & \multicolumn{7}{|c|}{ Cob weight(g) } \\
\hline & Tmax & Tmin & Tavg & GDD & ADT & ANT & AcDVT \\
\hline $\mathbf{P}_{1}$ & -0.21 & -0.06 & -0.14 & -0.20 & -0.13 & -0.10 & -0.18 \\
\hline $\mathbf{P}_{2}$ & -0.34 & -0.34 & -0.34 & -0.14 & -0.33 & -0.35 & 0.41 \\
\hline $\mathbf{P}_{3}$ & -0.28 & -0.38 & -0.32 & -0.27 & -0.31 & -0.32 & 0.57 \\
\hline $\mathbf{P}_{4}$ & -0.31 & -0.27 & -0.30 & -0.20 & -0.29 & -0.29 & -0.08 \\
\hline $\mathbf{P}_{5}$ & -0.32 & -0.37 & -0.34 & -0.24 & -0.33 & -0.34 & 0.57 \\
\hline \multirow[t]{3}{*}{$\mathbf{P}_{6}$} & -0.32 & -0.32 & -0.32 & -0.24 & -0.30 & -0.31 & 0.14 \\
\hline & \multicolumn{7}{|c|}{ Cob yield(q/ha) } \\
\hline & Tmax & Tmin & Tavg & GDD & ADT & ANT & AcDVT \\
\hline $\mathbf{P}_{1}$ & $0.65^{*}$ & 0.41 & 0.55 & 0.42 & 0.56 & 0.51 & 0.17 \\
\hline $\mathbf{P}_{2}$ & $0.90 *$ & $0.94^{*}$ & $0.93 *$ & $0.71^{*}$ & $0.94 *$ & $0.94 *$ & -0.46 \\
\hline $\mathbf{P}_{3}$ & $0.94 *$ & $0.95^{*}$ & $0.95^{*}$ & $0.93^{*}$ & $0.95 *$ & $0.95^{*}$ & $-0.81^{*}$ \\
\hline $\mathbf{P}_{4}$ & $0.87 *$ & $0.84 *$ & $0.88^{*}$ & $0.46^{*}$ & $0.88^{*}$ & $0.85^{*}$ & $0.09 *$ \\
\hline $\mathbf{P}_{5}$ & $0.95^{*}$ & $0.97 *$ & $0.97 *$ & $0.95^{*}$ & $0.98^{*}$ & $0.98^{*}$ & $0.80^{*}$ \\
\hline \multirow[t]{3}{*}{$\mathbf{P}_{6}$} & $0.94 *$ & $0.93 *$ & $0.94 *$ & $0.63^{*}$ & $0.95^{*}$ & $0.97 *$ & $-0.20 *$ \\
\hline & \multicolumn{7}{|c|}{ Fodder yield (q/h) } \\
\hline & Tmax & Tmin & Tavg & GDD & ADT & ANT & AcDVT \\
\hline $\mathbf{P}_{1}$ & $0.70^{*}$ & 0.43 & 0.57 & 0.47 & 0.60 & 0.53 & 0.20 \\
\hline $\mathbf{P}_{2}$ & $0.93^{*}$ & $0.97^{*}$ & $0.97 *$ & $0.73^{*}$ & $0.97 *$ & $0.97 *$ & -0.49 \\
\hline $\mathbf{P}_{3}$ & $0.94 *$ & $0.95^{*}$ & $0.97 *$ & $0.92^{*}$ & $0.95^{*}$ & $0.97 *$ & $-0.83^{*}$ \\
\hline $\mathbf{P}_{4}$ & $0.91 *$ & $0.87^{*}$ & $0.90 *$ & $0.51 *$ & $0.9^{*}$ & $0.89 *$ & $0.12^{*}$ \\
\hline $\mathbf{P}_{5}$ & $0.97 *$ & $0.97 *$ & $0.99 *$ & $0.95^{*}$ & $0.99 *$ & $0.99 *$ & $-0.82 *$ \\
\hline$P_{6}$ & $0.97 *$ & $0.95^{*}$ & $0.97 *$ & $0.68^{*}$ & $0.98^{*}$ & $0.96^{*}$ & $-0.20^{*}$ \\
\hline
\end{tabular}


Table.2 Coefficients of variabilities of various weather parameters pertaining to different phenophase of baby corn across dates of sowing

\begin{tabular}{|c|c|c|c|c|c|c|}
\hline & \multicolumn{3}{|c|}{$\operatorname{Tmax}\left({ }^{\circ} \mathrm{C}\right)$} & \multicolumn{3}{|c|}{$\operatorname{Tmin}\left({ }^{\circ} \mathrm{C}\right)$} \\
\hline & MEAN & S.D. & C.V\% & MEAN & S.D. & C.V\% \\
\hline $\mathbf{P}_{1}$ & 27.9 & 3.06 & 10.9 & 14.3 & 3.11 & 21.7 \\
\hline $\mathbf{P}_{2}$ & 29.9 & 5.97 & 19.9 & 15.9 & 5.51 & 34.6 \\
\hline $\mathbf{P}_{3}$ & 29.6 & 5.39 & 18.2 & 15.5 & 5.68 & 36.5 \\
\hline $\mathbf{P}_{4}$ & 28.9 & 4.23 & 14.6 & 15.1 & 3.85 & 25.5 \\
\hline $\mathbf{P}_{5}$ & 29.8 & 5.52 & 18.6 & 15.7 & 5.49 & 34.9 \\
\hline \multirow[t]{3}{*}{$\mathbf{P}_{6}$} & 29.1 & 4.41 & 15.1 & 15.3 & 4.25 & 27.8 \\
\hline & \multicolumn{3}{|c|}{ T-avg $\left({ }^{\circ} \mathrm{C}\right)$} & \multicolumn{3}{|c|}{ GDD $\left({ }^{\circ} \mathrm{C}\right.$-days $)$} \\
\hline & MEAN & S.D. & C.V\% & MEAN & S.D. & C.V\% \\
\hline $\mathbf{P}_{1}$ & 21.1 & 3.00 & 14.2 & 871.3 & 133.39 & 15.3 \\
\hline $\mathbf{P}_{2}$ & 22.9 & 5.66 & 24.7 & 81.4 & 13.44 & 16.5 \\
\hline $\mathbf{P}_{\mathbf{3}}$ & 22.6 & 5.47 & 24.2 & 186.0 & 36.18 & 19.4 \\
\hline $\mathbf{P}_{4}$ & 22.0 & 3.99 & 18.1 & 952.7 & 142.62 & 14.9 \\
\hline $\mathbf{P}_{5}$ & 22.8 & 5.45 & 23.9 & 267.4 & 45.67 & 17.1 \\
\hline \multirow[t]{3}{*}{$\mathbf{P}_{6}$} & 22.2 & 4.28 & 19.3 & 1138.7 & 157.91 & 13.9 \\
\hline & \multicolumn{3}{|c|}{$\operatorname{ADT}\left({ }^{\circ} \mathrm{C}\right)$} & \multicolumn{3}{|c|}{ ANT $\left({ }^{\circ} \mathbf{C}\right)$} \\
\hline & MEAN & S.D. & C.V\% & MEAN & S.D. & C.V\% \\
\hline $\mathbf{P}_{1}$ & 22.4 & 3.04 & 13.56 & 19.7 & 3.05 & 15.5 \\
\hline $\mathbf{P}_{2}$ & 24.1 & 5.72 & 23.77 & 21.2 & 5.66 & 26.7 \\
\hline $\mathbf{P}_{\mathbf{3}}$ & 24.0 & 5.44 & 22.69 & 21.2 & 5.49 & 25.9 \\
\hline $\mathbf{P}_{4}$ & 23.3 & 4.09 & 17.60 & 20.5 & 4.03 & 19.7 \\
\hline $\mathbf{P}_{5}$ & 24.0 & 5.45 & 22.68 & 21.2 & 5.46 & 25.7 \\
\hline \multirow[t]{3}{*}{$\mathbf{P}_{6}$} & 23.5 & 4.32 & 18.38 & 20.71 & 4.29 & 20.7 \\
\hline & \multicolumn{3}{|c|}{ AcDVT $\left({ }^{\mathbf{0} C}\right.$-days $)$} & & & \\
\hline & MEAN & S.D. & C.V\% & & & \\
\hline $\mathbf{P}_{1}$ & 161.9 & 18.82 & 11.6 & & & \\
\hline $\mathbf{P}_{2}$ & 14.8 & 3.48 & 23.4 & & & \\
\hline $\mathbf{P}_{\mathbf{3}}$ & 34.1 & 6.65 & 19.5 & & & \\
\hline $\mathbf{P}_{4}$ & 88.3 & 9.00 & 10.2 & & & \\
\hline $\mathbf{P}_{5}$ & 24.4 & 4.53 & 18.5 & & & \\
\hline $\mathbf{P}_{6}$ & 70.3 & 6.45 & 9.2 & & & \\
\hline
\end{tabular}

Table.3 Duration of different phenophases and their variability of baby corn as influenced by dates of sowing (Pooled for two years)

\begin{tabular}{|c|c|c|c|c|c|c|c|c|}
\hline \multirow{2}{*}{ Pheno-phases } & \multicolumn{8}{|c|}{ Duration of different phenophases } \\
\cline { 2 - 9 } & $\mathrm{D}_{1}$ & $\mathrm{D}_{2}$ & $\mathrm{D}_{3}$ & $\mathrm{D}_{4}$ & $\mathrm{D}_{5}$ & MEAN & S.D & C.V\% \\
\hline $\mathbf{P}_{\mathbf{1}}$ & 58 & 62 & 64 & 59 & 55 & 59.3 & 3.43 & 5.8 \\
\hline $\mathbf{P}_{\mathbf{2}}$ & 7 & 6 & 5 & 5 & 4 & 5.2 & 1.04 & 19.9 \\
\hline $\mathbf{P}_{\mathbf{3}}$ & 15 & 14 & 12 & 11 & 10 & 12.2 & 2.02 & 16.5 \\
\hline $\mathbf{P}_{\mathbf{4}}$ & 64 & 68 & 69 & 63 & 59 & 64.5 & 3.90 & 6.1 \\
\hline $\mathbf{P}_{\mathbf{5}}$ & 21 & 20 & 17 & 15 & 14 & 17.4 & 3.05 & 17.5 \\
\hline $\mathbf{P}_{\mathbf{6}}$ & 79 & 82 & 81 & 74 & 69 & 76.7 & 5.37 & 7.0 \\
\hline
\end{tabular}


Table.4 Heat use efficiency $\left(\mathrm{kg} / \mathrm{ha} /{ }^{\circ} \mathrm{C}\right.$ days $)$ of baby corn as a function of spacing and dates of sowing

\begin{tabular}{|l|c|c|c|c|}
\hline & $\mathbf{S}_{\mathbf{1}}$ & $\mathbf{S}_{\mathbf{2}}$ & $\mathbf{S}_{\mathbf{3}}$ & \multicolumn{1}{c|}{ Mean } \\
\hline $\mathbf{D}_{\mathbf{1}}$ & 2.12 & 2.94 & 5.38 & 3.48 \\
\hline $\mathbf{D}_{\mathbf{2}}$ & 1.81 & 2.64 & 5.01 & 3.15 \\
\hline $\mathbf{D}_{\mathbf{3}}$ & 1.86 & 2.49 & 4.97 & 3.11 \\
\hline $\mathbf{D}_{\mathbf{4}}$ & 1.91 & 2.62 & 5.09 & 3.21 \\
\hline $\mathbf{D}_{\mathbf{5}}$ & 2.29 & 3.16 & 5.92 & 3.79 \\
\hline Mean & 2.00 & 2.77 & 5.27 & \\
\hline & \multicolumn{1}{|c|}{$\mathrm{D}$} & $\mathrm{S}$ & $\mathrm{D} \mathrm{X} \mathrm{S}$ & $\mathrm{S} \mathrm{X} \mathrm{D}$ \\
\hline S.Em(土) & 0.033 & 0.023 & 0.057 & 0.051 \\
\hline C.D.(5\%) & 0.109 & 0.07 & 0.162 & 0.167 \\
\hline
\end{tabular}

Fig.1 Impacts of phenophasic thermal regime on the cob yield of baby corn

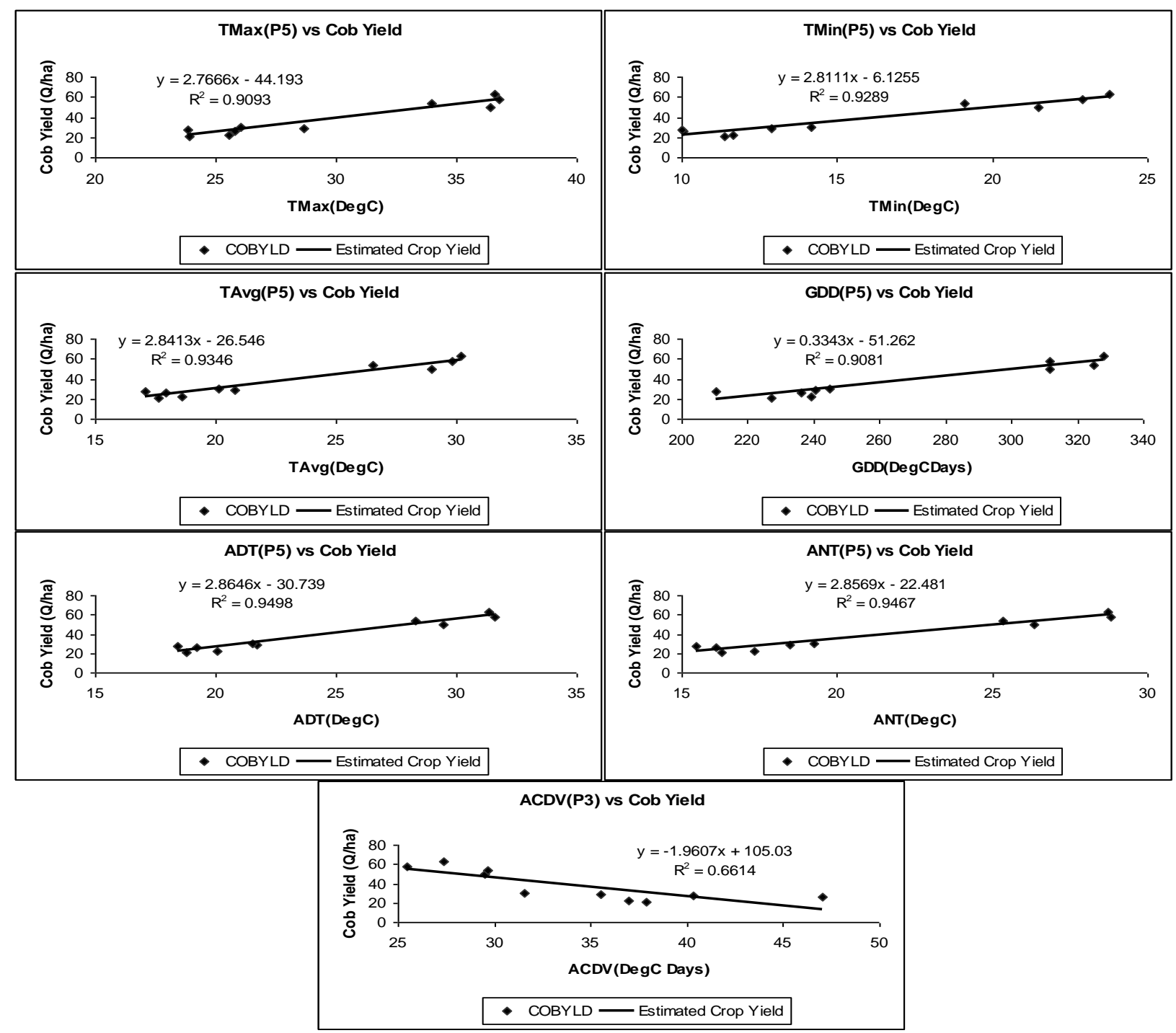


The difference in heat use efficiencies (HUE) values among the dates of sowing as well as among the spacing levels were statistically significant. Among the dates of sowing, maximum HUE was recorded for D5 sown crop and minimum HUE for D3 sown crop across the spacing levels. Higher HUE for baby corn crop grown during late rabi season under Tamilnadu condition was also obtained by Thavaprakash (2007). Highest HUE recorded during D5 was also associated with highest baby corn yield at this date of sowing. Sahoo and Panda (1999) got the highest yield of Baby corn in both wet and winter season. Where as,Basu et al., in 2009 noted that summer sown baby corn rendered maximum yield in baby corn. Borowiecki et al., (1992) reported that May sowing shortened the period from emergence to spikelet differentiation of the tassel and effective heat sums was 1299-1450 oC-days for May sowing. Baby corn sown at D5 recorded highest HUE vis-a-vis baby corn yield, which might be associated with the exposure of average Tmax of $35.4 \mathrm{oC}$ that favoured the crop yield level to its maximum.

In conclusion, higher average maximum temperature, even beyond $35^{\circ} \mathrm{C}$, during $50 \%$ flowering to harvest stage has been found to be beneficial for higher baby corn yield. Such thermal regime was obtained when the crop was sown on $15^{\text {th }}$ February in the new alluvial agroclimatic zone of West Bengal. It was also evident that equitable day-night temperature condition, as evidenced from lower values of accumulated diurnal variation of temperature, was congenial for higher baby corn yield. Yield-weather relationship studies clearly indicate that the crop is thermo- sensitive and performs better at higher thermal regimes.

\section{Acknowledgement}

Author would like to say thanks to Bidhan Chandra Krishi Viswavidyalay, where the research work has done. Also, like to say thanks to Professor Abhijit Saha and Professor Manas Kumar Pandit for their immense effort to complete the research work.

\section{References}

Basu, B., Kundu. C. K., Mondol. S., Bandopadhyay, P. and De, D.K. 2009. Evolution of forage production potential of maize grown for baby corn and green cob under new alluvial zone of West Bengal. India Agriculturist., 53(3/4): 177-181.

Borowiecki. J. 1992. Effect of the sowing date of maize cultivars with various lengths of growth period on the rates of development and ripening. PamietnikPuawski., 101: 123-136.

Chutkaew, C. and Paroda, R. S. 1994. Baby corn production in Thailand-a success story. FAO Regional Office for Asia \& the Pacific, Asia Pacific Association of Agricultural Research Institutions, APAARI Publication: 1994/1. 20pp.

El Shaer, M.H., El-Hattab, A.H., Khalil, N. A. and El Murshedi, W. A. 1991. Effect of planting date on growing degree days to different phenological stages and attributes related to yield in maize. Bulletin of Faculty of Agriculture, University of Cairo., 42(3): 687-699.

Haider, S.A., Alam, M. Z., Alam, A. F. and Raul, N. K. 2003. Influence of different sowing dates on the phenology and accumulated heat units in wheat. J. Biol. Sci., 3: 932-939.

Hemalatha, S., Sreelatha, D., Anuradha, M. and Sai Kumar, R. 2013. Crop weather relations in maize (Zea mays L.). J. Agrometeorol., 15(2): 165-166.

Kumar S. and Kalloo. G. (1998). Attributes of maize genotype for baby corn production. Maize genetics News Letter, Pp. 74. 
Sahoo, S.C. and Panda M.M. 1999. Effect of level of nitrogen and plant population on yield of baby com. (Zea mays L.). Ind. J. Agric Sci., 69(2): 157-158.

Shanmugavelu, K.G. 1989. Production technology of vegetable crops. Pub: Oxford\& IBH publishing Co. Pvt. Ltd. New Delhi, pp. 23-24.

Thavaprakaash, N and Velayudham, K. 2008. Light interception and productivity of baby corn as influenced by crop geometry intercropping system and INM practices. Asian. J. Sci. Res., 1(1):
72-78.

Vanaja, M., Sathish, G., Vijay Kumar, G., Razzaq, A., Vagheera, P., Lakshmi, N. J., Yadav, S. K., Sarkar, B. and Mahaswari, M. 2017. Elevated temperature and moisture deficit stress impact on phenology, physiology and yield responses of hybrid maize. $J$. Agrometeorol., 19(4): 295-300.

Venkatraman, S. and Krishan, A. 1992. Crops and weather, ICAR, New Delhi, India, pp. 586.

\section{How to cite this article:}

Sanjay Bairagi, Abhijit Saha, M. K. Pandit and Arindam Das. 2020. Phenology and Yield of Baby Corn (Zea mays var. rugosa) as Influenced by Thermal Regime. Int.J.Curr.Microbiol.App.Sci. 9(10): 1361-1369. doi: https://doi.org/10.20546/ijcmas.2020.910.163 